\title{
Sete teses sobre os Direitos Humanos ${ }^{1}$
}

\author{
Seven theses on Human Rights
}

Costas Douzinas

\section{Sete teses sobre direitos humanos: parte 1}

Tese 1: A ideia de "humanidade" não tem significado fixo, nem pode agir como fonte de regras morais ou legais. Historicamente, tal ideia foi utilizada para classificar as pessoas em plenamente humanas, menos humanas e inumanas.

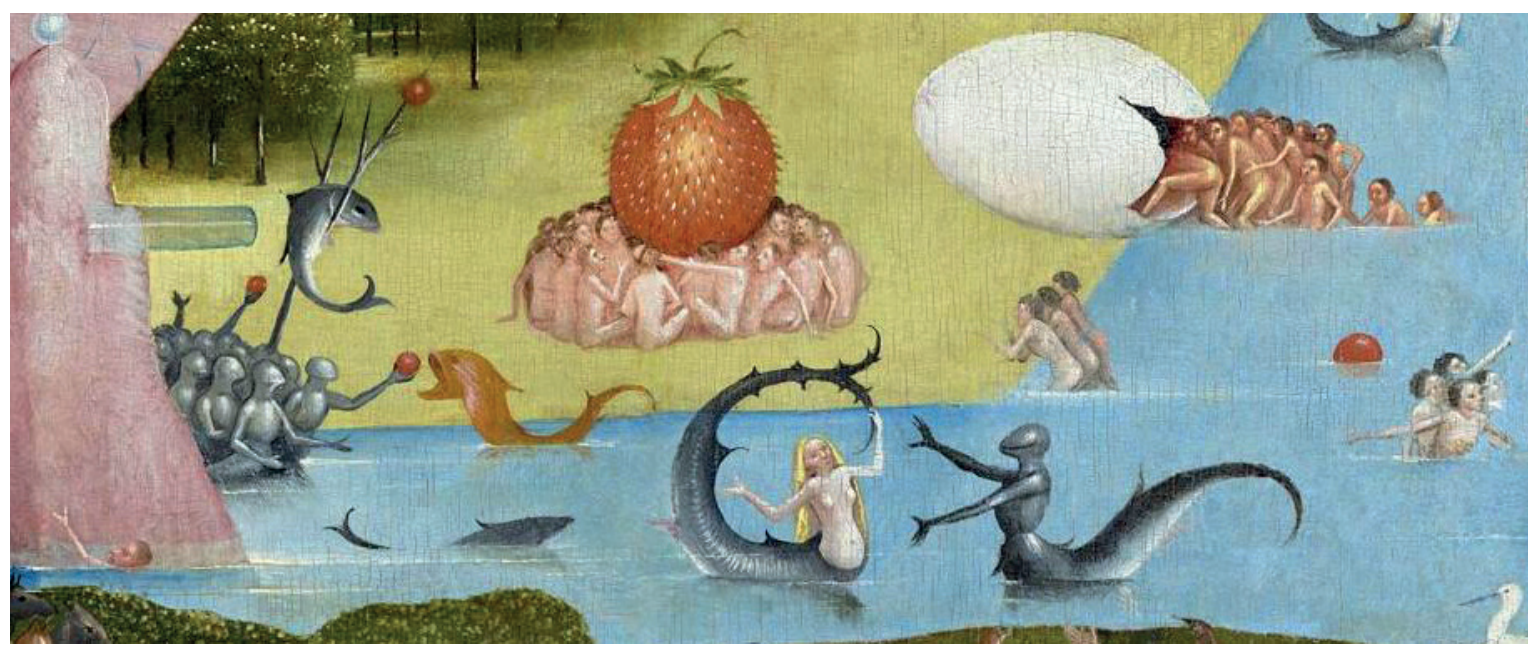

Se a "humanidade" é fonte normativa de regras morais e legais, sabemos o que é "humanidade"? Importantes questōes filosóficas e ontológicas estão envolvidas aqui. Deixe-me dar uma breve olhada em sua história.
As sociedades pré-modernas não desenvolveram uma ideia abrangente da espécie humana. Os homens livres eram atenienses ou espartanos, romanos ou cartagineses, mas não membros da humanidade; eram gregos ou bárbaros, mas não humanos.

\footnotetext{
${ }^{1}$ Traduçāo do texto de autoria do Professor Costas Douzinas publicado na página da "Critical Legal Thinking" no dia 30 de maio de 2013: http://criticallegalthinking.com/2013/05/30/seven-theses-on-human-rights-4-universalism-communitarianism-are-interdependent/. Este escrito consiste na tradução das quatro primeiras teses sobre Direitos Humanos de autoria de Costas Douzinas, denominou-se de "Parte 1" a reunião dos textos: "(1) A ideia de humanidade"; "(2) Poder, moralidade e exclusão institucional"; "(3) Capitalismo neoliberal e imperialismo voluntário"; "(4) Universalismo e Comunitarismo são interdependentes". Trad. de Daniel Carneiro Leão Romaguera, Manoel Uchôa de Oliveira, e Antonio Henrique Pires dos Santos .
} 
De acordo com a filosofia clássica, a natureza humana determinada teleologicamente distribuía as pessoas em hierarquias e papéis e as dotava de características diferenciadas. A palavra humanitas apareceu pela primeira vez na República Romana, como a tradução da palavra grega paideia. Ela foi definida como eruditio et institutio in bonas artes (o equivalente moderno mais próximo é o "Bildung" alemão). Os romanos herdaram o conceito do estoicismo e usaram-no para distinguir entre o homo humanus, o romano educado que estava familiarizado com a cultura e a filosofia grega e estava submetido ao jus civile, e os homines barbari, que incluíam a maioria dos habitantes não-romanos e não educados do Império. A humanidade entra no léxico ocidental como um atributo e predicado de homo, como um termo de separação e distinção. Para Cícero, também para o mais jovem Scipio, humanitas implica generosidade, polidez, civilização e cultura, aquilo que se opõe à barbárie e à animalidade. "Somente aqueles que estão em conformidade com certos padrōes são realmente homens em sentido pleno e totalmente merecedores do adjetivo "humano" ou do atributo "humanidade". ${ }^{3}$ Hannah Arendt coloca de forma sarcástica: "um ser humano ou homo no sentido original da palavra indica alguém fora da abrangência do direito e do corpo político de cidadãos, como por exemplo um escravo - mas certamente um ser politicamente irrelevante".

Se agora nos voltarmos para os usos políticos e jurídicos de humanitas, uma história semelhante emerge. O conceito "humanidade" tem sido constantemente usado para separar, distribuir e classificar as pessoas em governantes, governados e excluídos. "Humanidade" atua como uma fonte normativa à política e ao direito, contra um pano de fundo de desumanidade variável. Esta estratégia de separação política entrou curiosamente para o campo histórico no preciso momento em que a primeira concepção propriamente universalista de humanitas emergiu na teologia cristã, capturada na declaração de São Paulo, de que não há grego ou judeu, homem ou mulher, homem livre ou escravo (Epístola aos Gálatas 3:28). Todas as pessoas são igualmente parte da humanidade porque podem ser salvas pelo plano de salvação de Deus, porque compartilham dos atributos de humanidade agora acentuadamente diferenciados entre a divindade transcendental e a animalidade subumana. Para o humanismo clássico, a razão determina o humano: o homem é um zoon logon echon ou animale rationale. Por outro lado, segundo a metafísica cristã, a alma imortal, ao mesmo tempo carregada e enclausurada pelo corpo, é a marca da humanidade. A nova ideia de igualdade universal, desconhecida para os gregos, chegou ao mundo ocidental pela combinação das metafísicas clássica e cristã.

A ação divisória de "humanidade" sobreviveu à invenção da sua igualdade espiritual. Papa, Imperador, Príncipe, Rei, representantes e discípulos de Deus na terra foram governantes absolutos. E seus súditos, sub-jecti ou sub-diti, receberam a lei e seus comandos dos seus superiores políticos. Mais importante, as pessoas seriam salvas em Cristo apenas se aceitarem a fé, uma vez que os não cristãos não têm lugar no plano providencial. Estas divisão e exclusão radicais fundaram a missão ecumênica e o proselitismo da Igreja e do Império. A Lei espiritual do amor de Cristo se transformou em um grito de guerra: vamos trazer os pagãos para a graça de Deus; vamos fazer o evento singular de Cristo universal; vamos impor a mensagem da verdade e do amor sobre o mundo inteiro. A separação clássica entre o grego (ou humano) e o bárbaro foi baseada em fronteiras territoriais e linguísticas claramente demarcadas. No império cristão, a fronteira foi internalizada e

\footnotetext{
${ }^{2}$ Hannah Arendt, On Revolution (New York: Viking Press, 1965), 107.

${ }^{3}$ B.L. Ullman, "What are the Humanities?" Journal of Higher Education17/6 (1946), at 302.

${ }^{4}$ H.C. Baldry, The Unity of Mankind in Greek Thought, (Cambridge: Cambridge University Press 1965), 201.
} 
dividiu o mundo conhecido diagonalmente entre fiéis e pagãos. Os bárbaros não eram mais aqueles além da cidade, já que esta se expandiu para todo o mundo conhecido. Eles se tornaram os "inimigos internos" a serem devidamente corrigidos ou eliminados, caso teimosamente recusassem a salvação espiritual ou secular.

O significado de humanidade após a conquista do "Novo Mundo" foi vigorosamente contestado em um dos debates públicos mais importantes da história. Em abril de 1550, Carlos V da Espanha convocou um conselho de estado em Valladolid para discutir a atitude espanhola para com os índios derrotados do México. O filósofo Ginés de Sepúlveda e o Bispo Bartholomé de Las Casas, duas grandes figuras do lluminismo espanhol, debateram em lados opostos. Sepúlveda, que acabara de traduzir A Política de Aristóteles para o espanhol, argumentou que "os espanhóis governam de pleno direito os bárbaros que, em prudência, talento, virtude e humanidade são tão inferiores aos espanhóis quanto as crianças aos adultos, as mulheres aos homens, o selvagem e cruel ao leve e suave, eu poderia dizer o macaco ao homem".5 A coroa espanhola não deveria sentir nenhum escrúpulo em lidar com o mal indígena. Os índios poderiam ser escravizados e tratados como bárbaros e escravos selvagens a fim de serem civilizados e convertidos.

Las Casas discordou. Os índios têm costumes bem estabelecidos e modos de vida enraizados, argumentou ele, valorizam a prudência e têm a capacidade de governar e organizar suas famílias e cidades. Eles têm as virtudes cristãs da bondade, tranquilidade, simplicidade, humildade, generosidade e paciência, e estão esperando para serem convertidos. Eles se parecem com nosso pai Adão antes da queda, são cristãos "involuntários", escreveu Las Casas em sua Apologia. Em uma definição inicial do humanismo, Las Casas afirmou "todas as pessoas do mundo são humanos sob uma única definição para a totalidade dos humanos e para cada um, qual seja, são racionais... Assim, todas as raças da humanidade são uma só". 6 Seus argumentos combinam teologia cristā e utilidade política. Respeitar os costumes locais não é só boa moral, mas também boa política: os índios se convertem ao cristianismo (principal preocupação de Las Casas), mas também aceitam a autoridade da Coroa e enchem seus cofres, caso sentissem que suas tradiçōes, leis e culturas são respeitadas. Entretanto, o universalismo cristão de Las Casas era, como todos os universalismos, excludente. Repetidamente, condenou "turcos e mouros, os verdadeiros bárbaros desterrados das nações", uma vez que não podiam ser vistos como cristãos "involuntários". O universalismo "empírico" de superioridade e hierarquia (Sepúlveda) e a normatividade da verdade e do amor (Las Casas) acabam não sendo muito diferentes um do outro. Como Tzvetan Todorov comenta sucintamente, há “(...) violência na convicção de que possuem a verdade em si mesmo, ao passo que isto não é o caso para os outros, e que se deve, além disso, impor esta verdade sobre os outros"?

As interpretaçōes conflitantes sobre a "humanidade" de Sepúlveda e de Las Casas permitem capturar as ideologias dominantes de impérios ocidentais, imperialismos e colonialismos. Por um lado, o outro (racial) é desumano ou subumano. O que justifica a escravidão, as atrocidades e até mesmo a aniquilação como estratégia da missão civilizadora. Do outro extremo, conquista, ocupação e conversão forçada são estratégias de desenvolvimento espiritual ou material, do progresso e da integração dos inocentes, ingênuos e não desenvolvidos outros ao corpo principal da humanidade.

\footnotetext{
${ }^{5}$ Ginés de Sepulveda, Democrates Segundo of De las Justas Causa de la Guerra contra los Indios (Madrid: Institute Fransisco de Vitoria, 1951), 33 quoted in Tzvetan Todorov, The Conquest of America trans. Richard Howard (Norman: University of Oklahoma Press, 1999), 153.

${ }^{6}$ Bartholomé de las Casas, Obras Completas, Vol. 7 (Madrid: Alianza Editorial, 1922), 536-7.

${ }^{7}$ Todorov, The Conquest of America 166, 168.
} 
Essas duas definiçōes e estratégias de lidar com a alteridade conferem suporte à subjetividade ocidental. O desamparo, a passividade e a inferioridade dos outros "subdesenvolvidos" são transformados em nossa narcisista imagem refletida no espelho e potencial duplo. Esses desafortunados são as crianças da humanidade, são vitimizados e sacrificados por seus próprios malfeitores radicais; são resgatados pelo Ocidente que os ajuda a crescer, a desenvolver e a se tornar a nossa semelhança. Porque a vítima é a nossa imagem no espelho, nós sabemos qual é o seu interesse e devemos impô-lo "para seu próprio bem". Por outro lado, os irracionais, cruéis e vitimizados são projeçōes do Outro de nosso inconsciente. Como Slavoj Žižek coloca, "há uma espécie de exposição passiva a uma alteridade esmagadora que é a base do ser humano... [o desumano] é marcado por um excesso aterrorizante que, embora negue o que entendemos por humanidade, é inerente ao ser humano". Temos chamado este abismal outro que espreita na psique e transtorna o ego de vários nomes: Deus ou Satanás, bárbaro ou estrangeiro, a pulsão de morte ou o Real em psicanálise. Hoje, tornaram-se o "eixo do mal", o "Estado vadio", o "falso refugiado" ou o imigrante "ilegal". Eles são herdeiros contemporâneos dos "macacos" de Sepúlveda, representantes épicos de desumanidade.

Uma comparação das estratégias cognitivas associadas com o latino humanitas e o grego Anthropos é elucidativa. A humanidade do humanismo (e das ciências humanas) ${ }^{9}$ unifica o sujeito que conhece e o objeto conhecido seguindo os protocolos de autorreflexão. O anthropos da antropologia física e social, por outro lado, é o objeto apenas da cognição. A antropologia física examina corpos, sentidos e emoçōes, ou seja, suportes materiais da vida. Estudos de antropologia social diversificam povos não-ocidentais, sociedades e culturas, mas não a espécie humana em sua essência ou totalidade. Esses povos emergiram e se tornaram o objeto de observação e estudo pela descoberta, conquista e colonização do Novo Mundo, África, Ásia ou nas periferias da Europa. Nishitani Osamu afirma que a humanidade e o anthropos significam dois regimes assimétricos de conhecimento. A humanidade é a civilização, enquanto o anthropos está fora ou antes da civilização. Em nosso mundo globalizado, as literaturas menores do anthropos são examinadas pela literatura comparada que relaciona a "civilização" com culturas inferiores.

O gradual declínio do domínio ocidental está modificando essas hierarquias. Da mesma forma, a inquietação com um universalismo normativo, baseado em uma falsa concepção da humanidade, indica a ascensão de normatividades locais, concretas e vinculadas a um contexto.

Conclui-se, então, que a "humanidade", por não ter sentido unívoco, não pode atuar como uma fonte moral de normas. Seu sentido e alcance continuam a mudar de acordo com as prioridades políticas e ideológicas. As concepçōes de humanidade em constante mudança são as melhores manifestações da metafísica de uma época. Talvez tenha chegado o tempo para o anthropos substituir o humano. Talvez os direitos vindouros sejam antrópicos (para cunhar um termo), em vez de humanos, expressando e promovendo singularidades e diferenças, ao invés da mesmice e da equivalência de identidades até então dominantes.

Tradução do texto de autoria do Professor Costas Douzinas publicado na página da "Critical Legal Thinking" no dia 16 de maio de 2013. Link de acesso: http://criticallegalthinking.com/2013/05/16/ seven-theses-on-human-rights-1-the-idea-of-humanity/

\footnotetext{
${ }^{8}$ Slavoj Žižek, "Against Human Rights 56," New Left Review (July-August 2005), 34.

${ }^{9}$ Costas Douzinas, "For a Humanities of Resistance," Critical Legal Thinking, December 7, 2010, http://www.criticallegalthinking.com/2010/12/07/ for-a-humanities-of-resistance/
} 


\section{Sete teses sobre Direitos Humanos: (2) Poder, moralidade e exclusão institucional}

21 de Maio de 2013

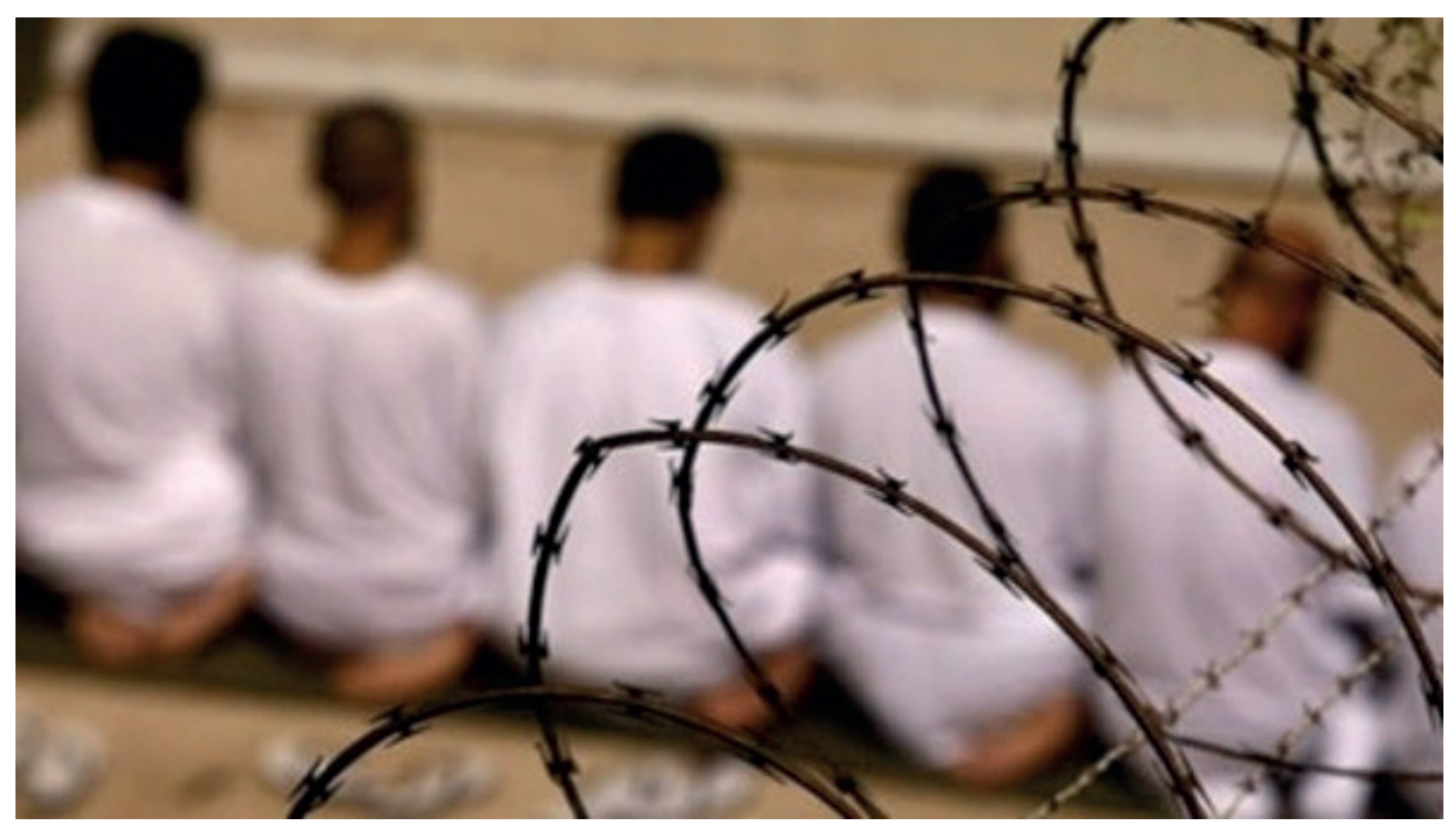

Vamos explorar a forte ligação interna entre esses princípios aparentemente antagônicos, no momento de seu surgimento ao final do século 18 na Europa e também na ordem internacional pós-1989. Esta será analisada no próximo texto.

A fundamentação religiosa da humanidade foi minada pelas filosofias políticas e liberais do início da modernidade. A fundação da humanidade foi transferida de Deus para a natureza (humana). A natureza humana tem sido interpretada como fato empírico, um valor normativo ou ambos. A ciência tem optado pela primeira abordagem. A marca da humanidade foi por diversas vezes procurada na linguagem, na razão ou na evolução. O homem como espécie surgiu do resultado de inovaçōes legais e políticas. A ideia de humanidade é uma criação do humanismo, tendo o humanismo legal em sua vanguarda. De fato, as grandes revoluçōes e declaraçōes do século 18, de forma paradigmática, expressaram e ajudaram a construir o universalismo moderno. Mas, no coração do humanismo, a humanidade-permaneceu como estratégia de divisão e classificação.

Nós podemos observar brevemente este processo contraditório, que tanto proclama o universal como exclui o local no texto da Declaração Francesa dos Direitos do Homem e do Cidadão, o grande manifesto da modernidade. Em seu Artigo $1^{\circ}$ - progenitor do universalismo normativo - afirma: "os homens nascem e são livres e iguais em direitos", uma reivindicação reproduzida no artigo inaugural da Declaração Universal dos Direitos Humanos de 1948. Igualdade e liberdade são declaradas estatutos naturais que independem de governos, de época e de questōes locais. Entretanto, a Declaração é categoricamente elucidativa sobre a fonte real dos direitos universais. Em seu Artigo 2ㅇ: "A finalidade de toda associação política é a conservação dos direitos naturais e imprescritíveis do homem (...)", pros- 
segue por definir esta associação no artigo 3‥ "O princípio de toda a soberania reside, essencialmente, na nação".

Os direitos "naturais" e eternos são declarados em nome do "homem" universal. No entanto, esses direitos não preexistem, mas são criados pela Declaração. Um novo tipo de associação política, a nação soberana e o estado, bem como um novo tipo de "homem", o cidadão nacional, nasceram e se tornaram beneficiários dos direitos. Assim, de maneira paradoxal a declaração de princípio universal estabelece a soberania local. A partir desse ponto, a estatalidade e seu território seguem o princípio nacional e pertencem a um tempo dual. Se a declaração inaugurou a modernidade, também deu início ao nacionalismo e suas consequências: genocídios, guerras civis, limpeza étnica, minorias, refugiados e apátridas. O princípio espacial é evidente: todo estado e território deveriam ter sua nação única e dominante e cada nação ter o seu próprio estado - um catastrófico desenrolar para a paz, como mostrou sua aplicação extrema desde 1989.

O novo princípio temporal substituiu a escatologia religiosa por uma teleologia histórica, que promete o futuro pela sutura da humanidade e da nação. Esta teleologia tem duas variantes possíveis: ou a nação impōe seu domínio sobre a humanidade ou o universalismo sobrepōe-se às divisōes e identidades paroquiais. Ambas as variantes se fizeram evidentes quando os romanos transformaram o cosmopolitismo estoico na regulamentação legal e imperial do jus gentium. Na França, a primeira alternativa apareceu na guerra napoleônica, que, supostamente, teria espalhado a influência civilizadora através da conquista e da ocupação (de acordo com Hegel, Napoleão representava o espírito do mundo nas costas de um cavalo); enquanto a segunda fora o início de um cosmopolitismo moderno, no qual a escravidão foi abolida e foram reconhecidos direitos políticos aos colonizados por um limitado período após a Revolução. Da deformação imperial do cosmopolitismo estoico ao uso atual dos direitos humanos para legitimar a hegemonia global ocidental, cada universalismo normativo decaiu em imperialismo global. A divisão entre humanidade normativa e empírica resiste à cura, precisamente porque a normatividade universal tem sido invariavelmente definida por uma parte da humanidade.

A humanidade universal das constituições liberais foi a fundamentação normativa para divisão e exclusão. Abriu-se a lacuna entre o "homem" universal, o princípio ontológico da modernidade, e o cidadão nacional, com sua instanciação política e real beneficiário dos direitos. O Estadonação veio à existência pela exclusão de outros povos e nações. $\mathrm{O}$ sujeito moderno atinge sua humanidade ao adquirir direitos políticos de cidadania, que garantem sua admissão à natureza humana universal ao excluir desse status os outros. O estrangeiro como um não cidadão é o bárbaro moderno. Ele não tem direitos por não fazer parte do estado e é um ser humano inferior por não ser cidadão. Alguém é considerado homem em maior ou menor grau porque é cidadão em maior ou menor grau. O estrangeiro é a lacuna entre o homem e o cidadão.

Em nosso mundo globalizado, não ter a cidadania, ser apátrida ou refugiado, é o pior destino. Estritamente falando, os direitos humanos não existem: se eles são dados às pessoas em virtude de sua humanidade e não por serem membros de algum grupo, então os refugiados, os imigrantes sans papier e os prisioneiros da Baía de Guantánamo e de outros centros de detenção têm pouca ou nenhuma proteção legal, porém deveriam ser seus principais beneficiários. Eles têm poucos, se é que possuem algum, direitos, são legalmente abandonados, os "vida nua", os homines sacri da nova ordem mundial.

A mudança paradigmática sobre o tema foi conduzida e exemplificada pela personalidade jurídica. Como espécime, o "homem" dos direitos do homem aparece sem gênero, cor, história ou tradição. Ele não tem necessidades ou desejos, é um 
vaso vazio unido com todos os outros por meio de três traços abstratos: o livre-arbítrio, a razão e a alma (agora, a mente) - os elementos universais da essência humana. Este mínimo de humanidade permite que o "homem" reivindique autonomia, responsabilidade moral e subjetividade legal. Ao mesmo tempo, o homem empírico que efetivamente goza dos "direitos do homem" é um homem demasiadamente homem: abastado, heterossexual, branco, homem urbano, que condensa na sua pessoa a dignidade em abstrato da humanidade e as prerrogativas reais de pertencer à comunidade dos poderosos. A segunda exclusão, portanto, condiciona o humanismo, a humanidade e seus direitos. A humanidade exclui os homens impróprios, isto é, os homens de nenhuma propriedade ou decoro, os seres humanos sem rima e razão, mulheres e minorias raciais, sexuais e étnicas. Os direitos constroem seres humanos contrariamente a uma variável desumanidade ou antropologia. De fato, essas "condiçōes desumanas da humanidade", como Pheng Cheah as chamou, funcionam como pré-condiçōes quase transcendentais da vida moderna. ${ }^{10}$

A história contemporânea dos direitos humanos pode ser vista como a luta contínua e sempre falível para fechar a lacuna entre o homem abstrato e o cidadão concreto; ou seja, adicionar carne, sangue e sexo ao contorno pálido do "humano" e estender as dignidades e privilégios dos poderosos (as características da humanidade normativa) para a humanidade empírica. Isso não aconteceu, todavia, e é improvável que seja alcançado pela ação de direitos.

Traduçāo do texto de autoria do Professor Costas Douzinas publicado na página da "Critical Legal Thinking" no dia 21 de maio de 2013. Link de acesso: http://criticallegalthinking.com/2013/05/21/ seven-theses-on-human-rights-2-power-morality-structural-exclusion/ 


\section{Sete teses sobre Direitos Humanos: (3) Capitalismo neoliberal e imperialismo voluntárioo}

23 de maio de 2013

Tese 3: A ordem pós-1989 combina um sistema econômico que produz enormes desigualdades estruturais e opressão com ideologia jurídico-política promissora de dignidade e igualdade. Esta grave instabilidade contribui para seu desaparecimento.

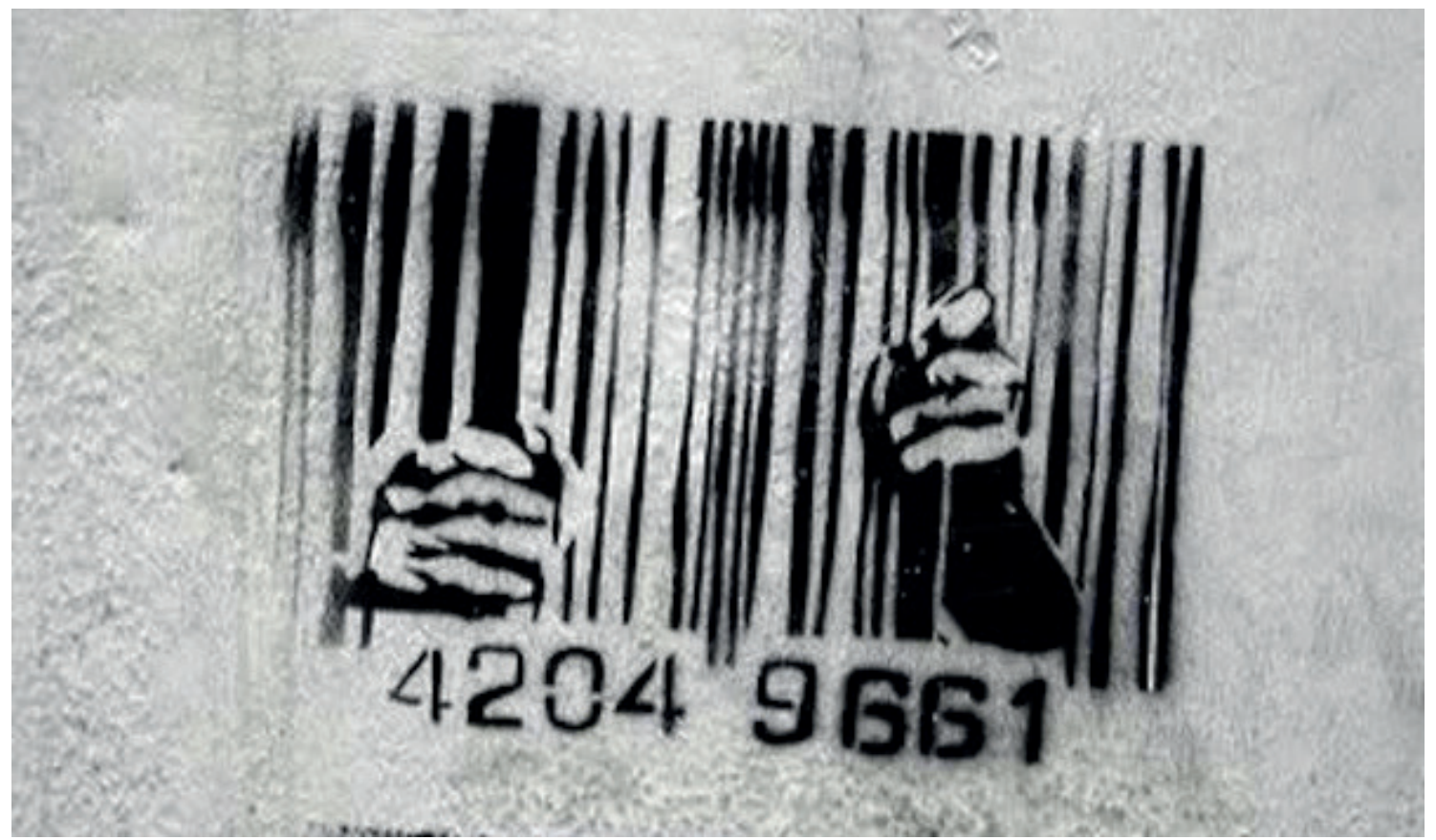

Por que razão e como essa combinação de capitalismo neoliberal e humanitarismo surge? O capitalismo sempre moralizou a economia e tentou conferir um brilho de justiça aos impulsos lucrativos e concorrência desregulada, precisamente porque é tão difícil de acreditar. Da "mão invisível" de Adam Smith à assertiva de que o egoísmo desenfreado promove o bem comum, ou que efeitos benéficos ocorrerão caso os ricos tenham ainda maiores reduções de impostos, o capitalismo tem consistentemente tentado reivindicar o mais alto patamar moral. ${ }^{11}$
De forma semelhante, os direitos humanos e sua disseminação não são simplesmente o resultado da disposição liberal ou caridade do Ocidente. O significado predominantemente negativo de liberdade como a ausência de restriçōes externas - um eufemismo para manter a regulação estatal da economia no mínimo - tem dominado a concepção ocidental de direitos humanos e os transformou no companheiro perfeito do neoliberalismo. A moral global e regras cívicas são os companheiros necessários da globalização da produção econômica e do consumo, ainda, da conclusão

${ }^{11}$ Jean-Claude Michéa, The Realm of Lesser Evil trans. David Fernbach (Cambridge and Malden: Polity Press, 2009), Chapter 3 
do capitalismo mundial que segue dogmas neoliberais. Ao longo dos últimos 30 anos, temos testemunhado, sem muito comentário, a criação de normas legais globais que regulam a economia capitalista mundial, incluindo regras sobre investimento, comércio, ajuda financeira e propriedade intelectual. Robert Cooper chamou este cenário de imperialismo voluntário de economia global: "É operado por um consórcio internacional de instituiçōes financeiras como o FMl e o Banco Mundial ... Essas instituiçōes ... fazem exigências, que enfatizam cada vez mais a boa governança. Os estados que desejam se beneficiar devem se abrir a interferência de organizaçōes internacionais e países estrangeiros. Cooper conclui: "o que é necessário, então, é um novo tipo de imperialismo, um aceitável para um mundo de direitos humanos e valores cosmopolitas". 12

A promessa (implícita) para o mundo em desenvolvimento é de que a adoção violenta ou voluntária orientada para o mercado, o modelo neoliberal de boa governança e os direitos limitados irá inexoravelmente levar a padrōes econômicos ocidentais. Isto é fraudulento. Historicamente, a capacidade do Ocidente de transformar a proteção dos direitos formais em garantia limitada de direitos materiais, econômicos e sociais, foi parcialmente baseada em enormes transferências das colônias para a metrópole. Enquanto a moralidade universal milita a favor de fluxo inverso, as políticas ocidentais de ajuda ao desenvolvimento e a dívida do Terceiro Mundo indicam que isto não é politicamente viável. De fato, as sucessivas crises e rearranjos do capitalismo neoliberal levaram à expropriação e deslocamento da agricultura familiar pelo agronegócio, à migração forçada e urbanização. Estes processos expandiram o número de pessoas sem habilidades, status ou condições básicas para manutenção de sua existência. Passam a ser os detritos humanos, a vida de resíduos, os bilhões de baixo. Esta ati- tude neocolonial tem se estendido da periferia para o núcleo europeu. Grécia, Portugal, Irlanda e Espanha foram submetidos aos rigores do neoliberal "Consenso de Washington" de austeridade e destruição do Estado de bem-estar, apesar de seu fracasso no mundo em desenvolvimento. Mais da metade dos jovens da Espanha e da Grécia estão permanentemente desempregados e toda uma geração está sendo destruída. Mas este "gene-cídio", para cunhar um termo, não gerou uma campanha por direitos humanos.

Como Immanuel Wallerstein coloca, "se todos os seres humanos têm direitos iguais, e todos os povos têm direitos iguais, então não podemos manter o tipo de sistema desigual que a economia mundial capitalista sempre foi e sempre será". ${ }^{13}$ Quando a intransponibilidade do fosso entre as declaraçōes missionárias sobre a igualdade e dignidade e a realidade sombria da desigualdade obscena se tornam aparentes, os direitos humanos levarão a novos e incontroláveis tipos de tensão e conflitos. Soldados espanhóis, quando do encontro dos exércitos de Napoleão, gritaram "Abaixo a liberdade!" Hoje em dia as pessoas se deparam com as "forças de paz" da nova ordem mundial com gritos de "Abaixo aos direitos humanos!".

Os sistemas sociais e políticos se tornaram hegemônicos ao transformar suas prioridades ideológicas em princípios e valores universais. $\mathrm{Na}$ nova ordem mundial, os direitos humanos são o candidato perfeito para este papel. Seus princípios fundamentais, interpretados negativamente e economicamente, permitem a penetração capitalista neoliberal. Sob uma construção diferente, suas disposiçōes abstratas poderiam sujeitar as desigualdades e indignidades do capitalismo tardio a ataque fulminante. Mas isso não pode acontecer enquanto forem utilizados pelos poderes dominantes para espalhar os "valores" de

\footnotetext{
12 Robert Cooper, “The New Liberal Imperialism," The Observer (April 1 2002), 3.

${ }^{13}$ Immanuel Wallerstein, "The Insurmountable Contradictions of Liberalism" Southern Atlantic Quarterly (1995), 176-7.
} 
uma ideologia baseada no niilismo e na insaciabilidade do desejo.

Apesar das diferenças de conteúdo, o colonialismo e o movimento dos direitos humanos formam um contínuo, são episódios do mesmo drama, que começou com as grandes descobertas do novo mundo e agora é realizado nas ruas do Iraque e do Afeganistão: levar a civilização aos bárbaros. 0 clamor por espalhar Razão e Cristianismo deu aos impérios ocidentais seu senso de superioridade e ímpeto por universalização. $\mathrm{O}$ impulso ainda está aqui; as ideias foram redefinidas, mas a crença na universalidade da nossa visão de mundo continua tão forte como a dos colonizadores. Há pouca diferença entre impor a razão e a boa governança e converter para o cristianismo e direitos humanos. Ambos fazem parte do pacote cultural do Ocidente, agressivo e redentor ao mesmo tempo.

Traduçāo do texto de autoria do Professor Costas Douzinas publicado na página da "Critical Legal Thinking" no dia 23 de maio de 2013. Link de acesso: http://criticallegalthinking.com/2013/05/23/seven-theses-on-human-rights-3-neoliberal-capitalism-voluntary-imperialism/ 


\section{Sete teses sobre Direitos Humanos: (4) Universalismo e Comunitarismo são interdependentes}

30 de maio de 2013

Tese 4: Universalismo e comunitarismo, ao invés de serem adversários, são dois tipos de humanismo dependentes um do outro. Ambos são confrontados pela ontologia da igualdade singular.

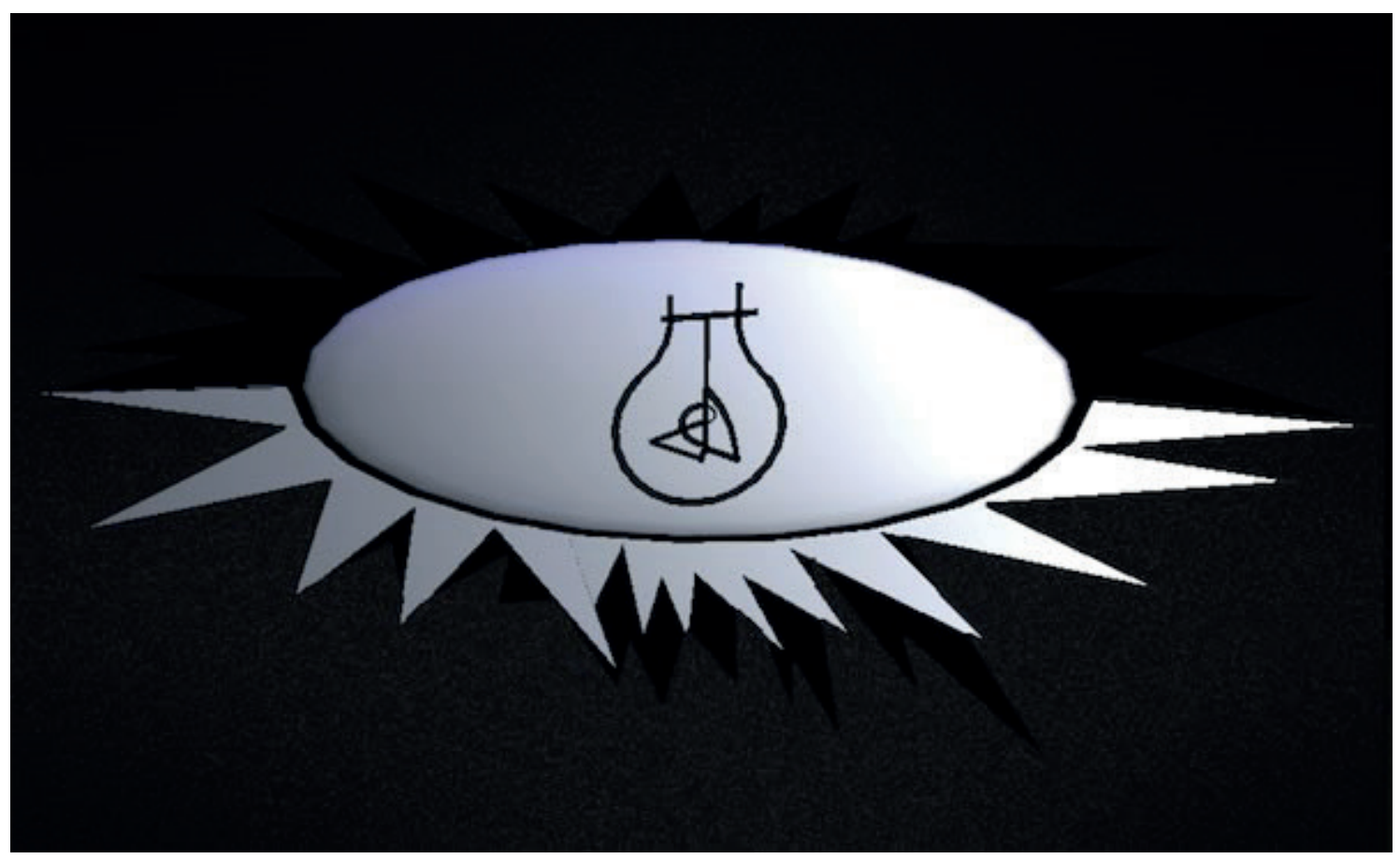

O debate sobre o significado de humanidade como fonte normativa é realizado entre universalistas e comunitaristas. O universalista afirma que os valores culturais e normas morais devem passar por um teste de aplicabilidade universal e consistência lógica e muitas vezes conclui que, se há uma verdade moral e muitos erros, cabe a seus agentes impô-la aos outros.

Os comunitaristas partem da observação óbvia de que os valores são vinculados ao contexto $e$ tentam impor esses valores àqueles que não concordam com a opressão da tradição. Ambos os princípios, quando se tornam essências absolu- tas e definem o significado e valor da humanidade sem deixar vestígios, podem achar dispensável tudo o que resiste a eles.

Kosovo é um bom exemplo. Os sérvios orgulhosos mataram e promoveram a "limpeza" étnica dos albaneses, a fim de proteger a integridade do "berço" de sua nação (curiosamente, como a maioria dos nacionalismos selvagens, celebrando uma derrota histórica). Os bombardeios da OTAN mataram pessoas - a 35.000 pés de altura - em Belgrado e Kosovo, a fim de defender os direitos de humanidade. Ambas as posiçōes exemplificam, talvez de maneiras diferentes, o impulso 
metafísico contemporâneo: eles tomaram uma decisão axiomática sobre o que constitui a essência da humanidade e seguem-na em desrespeito teimoso às alternativas. Eles são as expressões contemporâneas de um humanismo que define a "essência" da humanidade por todo o caminho até o seu fim, como telos e final. Parafraseando Emmanuel Levinas, para salvar o ser humano devemos derrotar esse tipo de humanismo.

O individualismo dos princípios universais esquece de que cada pessoa é um mundo e vem à existência em comum com os outros, que estamos todos em comunidade. Todo ser humano é um ser singular, único em sua existência como uma concatenação irrepetível de encontros passados, desejos e sonhos com projeções futuras, expectativas e planos. Cada pessoa forma um cosmo fenomenológico de significado e intencionalidade, considerado nas relaçōes de desejo e reconhecimento com os outros. Ser em comum é uma parte integrante do ser: o self é exposto ao outro, é levado à exterioridade, o outro é parte da intimidade de si mesmo. Meu rosto está "sempre exposto aos outros, sempre virado em direção a um outro e por ele ou ela encarado, nunca encarando a mim mesmo". ${ }^{14}$

De fato, ser em comunidade com os outros é o oposto de ser em comum ou de pertencer a uma comunidade essencial. Comunitaristas, por outro lado, definem comunidade pela comunhão da tradição, história e cultura, as várias cristalizaçōes passadas cujo peso inescapável determina possibilidades no presente. A essência da comunidade comunitária é muitas vezes compelir ou permitir que as pessoas encontrem sua "essência", a "humanidade" comum, agora definida como o espírito da nação, do povo ou do líder. Temos de seguir os valores tradicionais e excluir o que é es- tranho, o outro. A comunidade como comunhão aceita os direitos humanos apenas na medida em que ajudam a submergir o "Eu" ao "Nós", todo o caminho até à morte, o ponto da "comunhão absoluta" com a tradição morta. ${ }^{15}$

Ambas, moralidade universal e identidade cultural expressam diferentes aspectos da experiência humana. A sua comparação em abstrato é fútil e suas diferenças não são pronunciadas. Quando um estado adota direitos humanos universais, irá interpretá-los e aplicá-los, quando muito, de acordo com os procedimentos legais e princípios morais locais, tornando o universal servo do particular. O inverso também é verdadeiro: mesmo aqueles sistemas legais que prezam pelos direitos $e$ práticas culturais tradicionais contra a invasão do universal, já estão por ele contaminados. Todos os direitos e princípios, mesmo que paroquiais em seu conteúdo, compartilham do ímpeto universalizante de sua forma. Nesse sentido, direitos carregam a semente da dissolução da comunidade e a única defesa é resistir à ideia de direitos como um todo, algo impossível para o neoliberalismo global. As reivindicaçōes de universalidade e tradição, ao invés de estarem em combate mortal, tornaram-se aliados inquietos, cujo elo frágil foi sancionado pelo Banco Mundial.

De nossa perspectiva, a humanidade não pode agir como um princípio normativo. A humanidade não é uma propriedade compartilhada. Ela é discernível na incessante surpresa da condição humana e sua exposição a um futuro aberto e não decidido. Sua função não se encontra em uma essência filosófica, mas na sua não-essência, no processo interminável de re-definição e na necessária porém impossível tentativa de escapar a uma determinação externa. A humanidade não tem fundação $e$ nem fim; ela é a definição de sem fundamento.

\footnotetext{
${ }^{14}$ Jean-Luc Nancy, The Inoperative Community (Minneapolis: University of Minnesota Press, 1991), xxxviii. 


\section{Costas Douzinas}

Professor de Direito e Pró-Vice Reitor de Relaçōes Internacionais de Birkbeck (Universidade de Londres), Diretor do Birkbeck Institute for the Humanities e editor da revista internacional "Law \& Critique". 